\title{
Estimation of True Serum Thyroglobulin Concentration Using Simultaneous Measurement of Serum Antithyroglobulin Antibody
}

\author{
Byeong-Cheol Ahn, ${ }^{1}$ Won Kee Lee, ${ }^{2}$ Shin Young Jeong, ${ }^{1}$ Sang-Woo Lee, ${ }^{1}$ and Jaetae Lee ${ }^{1}$ \\ ${ }^{1}$ Department of Nuclear Medicine, Kyungpook National University School of Medicine/Hospital, 50 Samduk-dong 2-ga, Chung Gu, \\ Daegu 700-721, Republic of Korea \\ ${ }^{2}$ Department of Preventive Medicine, Kyungpook National University School of Medicine/Hospital, 50 Samduk-dong 2-ga, Chung Gu, \\ Daegu 700-721, Republic of Korea
}

Correspondence should be addressed to Byeong-Cheol Ahn; abc2000@knu.ac.kr

Received 30 November 2012; Revised 7 February 2013; Accepted 5 March 2013

Academic Editor: Eleonore Fröhlich

Copyright (C) 2013 Byeong-Cheol Ahn et al. This is an open access article distributed under the Creative Commons Attribution License, which permits unrestricted use, distribution, and reproduction in any medium, provided the original work is properly cited.

\begin{abstract}
We investigated the analytical interference of antithyroglobulin antibody ( $\mathrm{TgAb}$ ) to thyroglobulin $(\mathrm{Tg})$ measurement and tried to convert measured $\mathrm{Tg}$ concentration to true $\mathrm{Tg}$ concentration using a mathematical equation which includes a concentration of TgAb. Methods. Tg was measured by immunoradiometric assay and TgAb by radioimmunoassy. Experimental samples were produced by mixing Tg and TgAb standard solutions or mixing patients' serum with high Tg or high TgAb. Mathematical equations for prediction of expected Tg concentration with measured Tg and TgAb concentrations were deduced. The Tg concentration calculated using the equations was compared with the expected Tg concentration. Results. Measured Tg concentrations of samples having high $\mathrm{TgAb}$ were significantly lower than their expected Tg concentration. Magnitude of TgAb interference with the Tg assay showed a positive correlation with concentration of TgAb. Mathematical equations for estimation of expected Tg concentration using measured $\mathrm{Tg}$ and $\mathrm{TgAb}$ concentrations were successfully deduced and the calculated $\mathrm{Tg}$ concentration showed excellent correlation with expected Tg concentration. Conclusions. A mathematic equation for estimation of true Tg concentration using measured $\mathrm{Tg}$ and $\mathrm{TgAb}$ concentration was deduced. Tg concentration calculated by use of the equation might be more valuable than measured $\mathrm{Tg}$ concentration in patients with differentiated thyroid cancer.
\end{abstract}

\section{Introduction}

Thyroglobulin (Tg), a glycoprotein synthesized in normal or malignant thyroid follicular cells, is an important marker for residual or recurrent differentiated thyroid cancer. Undetectable $\mathrm{Tg}$ is one of the criteria to establish the absence of a persistent tumor or recurrence in patients with differentiated thyroid cancer who have undergone total thyroidectomy and remnant ablation with radioiodine $[1,2]$. Tg is the most sensitive marker for detecting recurrence of differentiated thyroid cancer; however, the presence of antithyroglobulin antibody $(\mathrm{Tg} A b)$ interferes with measurement of Tg; therefore, development of Tg assays with limited or no interference by $\mathrm{TgAb}$ and development of methods for clearing of $\mathrm{TgAb}$ prior to measurement of $\mathrm{Tg}$ are warranted $[1,3,4]$. Until now, no $\mathrm{TgAb}$-proof $\mathrm{Tg}$ assay (Tg assay without influence of $\mathrm{TgAb}$ ) has been made available, and the presence of $\mathrm{TgAb}$ causes the concentration of measured $\mathrm{Tg}$ to be lower than that of the true concentration [4-6].

In patients with differentiated thyroid cancer who underwent curative treatment with total thyroidectomy followed by high-dose radioiodine ablation, the cut off value of $\mathrm{Tg}$ for performance of imaging studies for detection of persistent disease or recurrence is variable, according to the status of TSH and the concentration of measured TgAb [1]. Despite the lack of an international consensus regarding the appropriate Tg cut off value for residual or recurrent disease [7], almost all institutions or physicians have their own cut off value 
TABLE 1: Expected Tg and TgAb concentrations of twenty experimental samples produced with standard solutions of Tg and TgAb. Values are expressed as $\mathrm{Tg}(\mathrm{ng} / \mathrm{mL})-\mathrm{TgAb}(\mathrm{U} / \mathrm{mL})$.

\begin{tabular}{lcccc}
\hline $2.0-10.0$ & $2.0-30.0$ & $2.0-100.0$ & $2.0-300.0$ & $2.0-1000.0$ \\
$10.0-10.0$ & $10.0-30.0$ & $10.0-100.0$ & $10.0-300.0$ & $10.0-1000.0$ \\
$50.0-10.0$ & $50.0-30.0$ & $50.0-100.0$ & $50.0-300.0$ & $50.0-1000.0$ \\
$125.0-10.0$ & $125.0-30.0$ & $125.0-100.0$ & $125.0-300.0$ & $125.0-1000.0$ \\
\hline
\end{tabular}

TABLE 2: Expected Tg and TgAb concentrations of twenty experimental samples produced with patient serums. Values are expressed as $\operatorname{Tg}(\mathrm{ng} / \mathrm{mL})-\operatorname{TgAb}(\mathrm{U} / \mathrm{mL})$.

\begin{tabular}{lcccc}
\hline $4.7-3.5$ & $4.7-5.2$ & $4.7-18.8$ & $4.7-643.0$ & $4.7-930.0$ \\
$18.5-3.5$ & $18.5-5.2$ & $18.5-18.8$ & $18.5-643.0$ & $18.5-930.0$ \\
$111.0-3.5$ & $111.0-5.2$ & $111.0-18.8$ & $111.0-643.0$ & $111.0-930.0$ \\
$246.0-3.5$ & $246.0-5.2$ & $246.0-18.8$ & $246.0-643.0$ & $246.0-930.0$ \\
\hline
\end{tabular}

for predicting persistent or recurrent disease according to TSH status (stimulated or not stimulated). Another factor to consider in interpretation of measured $\mathrm{Tg}$ value is the presence or absence of $\mathrm{TgAb}$, the strongest serologic factor interfering in accuracy of available Tg assays $[3,8]$. Measurement of TSH-stimulated Tg can result in failure to identify significant persistent or recurrent tumors in patients with $\mathrm{TgAb}$. Influential magnitude of $\mathrm{TgAb}$ on measurement of Tg is known to show correlation with the concentration of measured $\operatorname{TgAb}$ [4]. In addition, it has been also known that $\mathrm{Tg}$ radioimmunoassay is less prone to the influence than other immunometric assays. Recently, Locsei et al. reported that decrease of measured $\mathrm{Tg}$ concentration by adding sheep $\mathrm{TgAb}$ from the electrochemiluninometric $\mathrm{Tg}$ assay and the magnitude of the influence was significant even in the reference range [9].

In this study, the authors assessed the influence of $\mathrm{TgAb}$ on measurement of $\mathrm{Tg}$ and developed a mathematical equation for estimation of true $\mathrm{Tg}$ concentration under various concentrations of $\mathrm{TgAb}$ using data from experiments that employed both standard solutions of $\mathrm{Tg}$ and $\mathrm{TgAb}$ measurement kits and patients' serum having high Tg or high TgAb.

\section{Materials and Methods}

2.1. Tg Measurements. Tg was measured by immunoradiometric assay (IRMA) using a commercial reagent set (Dynotest Tg-plus; Brahms Diagnostica, Berlin, Germany, detection limit; $0.08 \mathrm{ng} / \mathrm{mL}$, measuring range; up to $250 \mathrm{ng} / \mathrm{mL}$ ) according to the manufacturer's recommendations. The method described by the manufacturer is as follows. Standard solution or experimental serum $(100 \mu \mathrm{L})$ is pipetted into test tubes coated with polyclonal TgAb. The tubes are then incubated for 18 hours at room temperature, and washed twice with $2 \mathrm{~mL}$ of washing solution. The tubes are turned upside down on blotting paper for at least 10 minutes. The tubes are again turned right side up, followed by addition of $200 \mu \mathrm{L}$ of ${ }^{125}$ I-labeled monoclonal TgAb.
The tubes are incubated for 2-3 hours at room temperature with shaking (300-400 rpm), followed by washing twice with $2 \mathrm{~mL}$ of washing solution. The tubes are then turned upside down again on blotting paper for at least 10 minutes. Radioactivity of each tube is then measured. Concentration of $\mathrm{Tg}$ is obtained using a standard curve derived using the standard solutions.

2.2. $\mathrm{TgAb}$ Measurements. TgAb was measured by radioimmunoassay (RIA) using a commercial reagent set (Dynotest anti-Tgn; Brahms Diagnostica, Berlin, Germany, detection limit; $5.5 \mathrm{U} / \mathrm{mL}$, measuring range; up to $\sim 2000 \mathrm{U} / \mathrm{mL}$ ) according to the manufacturer's recommendations. The method described by the manufacturer is as follows: standard solution or test serum $(20 \mu \mathrm{L})$ is pipetted into test tubes coated with polyclonal anti-TgAb, followed by addition of $200 \mu \mathrm{L}$ of ${ }^{125} \mathrm{I}$-labeled $\mathrm{Tg}$ to the tubes. The tubes are incubated for 2 hours at room temperature with shaking (300$400 \mathrm{rpm}$ ), followed by washing three times with $2 \mathrm{~mL}$ of washing solution. The tubes are then turned upside down on blotting paper for at least 10 minutes. Radioactivity of each tube is then measured. Concentration of $\mathrm{TgAb}$ is obtained using a standard curve derived using standard solutions.

2.3. Preparation of Experimental Samples. Several concentrations of $\mathrm{Tg}$ standard solutions (4.0, 20.0, 100.0, and $250.0 \mathrm{ng} / \mathrm{mL}$, Dynotest Tg-plus) and several concentrations of TgAb standard solutions $(20.0,60.0,200.0,600.0$, and $2000.0 \mathrm{U} / \mathrm{mL}$, Dynotest anti-Tgn) were prepared. In order to generate experimental samples containing various concentrations of $\mathrm{Tg}$ and $\mathrm{TgAb}$, equal volumes of standard solutions were mixed (Table 1). Serum samples containing various concentrations of $\operatorname{Tg}(9.3,37.6,221.9$, and $492.0 \mathrm{ng} / \mathrm{mL})$ with a low level of $\mathrm{TgAb}(<20 \mathrm{U} / \mathrm{mL})$ and serum samples containing various concentrations of $\operatorname{TgAb}(7.0,10.4,37.5,1286.0$, and 1860.0 U/mL) without $\mathrm{Tg}(<0.1 \mathrm{ng} / \mathrm{mL})$ were collected. All the serum samples were obtained from patients with differentiated thyroid cancer. In order to generate experimental samples with various concentrations of $\mathrm{Tg}$ and $\mathrm{TgAb}$, equal volumes of serum samples were also mixed (Table 2 ). In order to test reproducibility of measured $\mathrm{Tg}$ concentration for the experimental samples, triple samples were prepared for each concentration of every experimental sample produced using standard solutions or patients' serum.

2.4. Statistics and Deduction of Equations for Prediction of True Tg. Reproducibility of Tg measurement was tested. Influence of $\mathrm{TgAb}$ on measurement of Tg was analyzed and equations predicting expected (true) Tg concentration with measured $\mathrm{Tg}$ and $\mathrm{TgAb}$ concentration were deduced using the SAS program (version 9.22, SAS Institute Inc., Cary, NC, USA). $P<0.05$ was considered significant.

\section{Results}

3.1. Reproducibility of $\mathrm{Tg}$ Measurement. Reproducibility of $\mathrm{Tg}$ measurement performed on triplicate samples of each concentration of experimental samples produced using either 
TABLE 3: Decline of measured Tg value by TgAb in samples produced using Tg and TgAb standard solutions.

\begin{tabular}{|c|c|c|c|c|c|}
\hline \multirow{2}{*}{$\begin{array}{l}\text { Expected Tg concentration } \\
(\mathrm{ng} / \mathrm{mL})\end{array}$} & \multicolumn{5}{|c|}{$\begin{array}{l}\text { Measured Tg concentration }(\mathrm{ng} / \mathrm{mL}) \\
\text { under various } \mathrm{TgAb} \text { concentrations }\end{array}$} \\
\hline & $10.0 \mathrm{U} / \mathrm{mL}$ & $30.0 \mathrm{U} / \mathrm{mL}$ & $100.0 \mathrm{U} / \mathrm{mL}$ & $300.0 \mathrm{U} / \mathrm{mL}$ & $1000.0 \mathrm{U} / \mathrm{mL}$ \\
\hline 2.0 & $5.1 \pm 0.1$ & $4.0 \pm 0.2$ & $3.4 \pm 0.1$ & $2.6 \pm 0.1$ & $1.8 \pm 0.1$ \\
\hline 10.0 & $13.0 \pm 0.5$ & $11.8 \pm 0.4$ & $10.9 \pm 0.7$ & $10.0 \pm 0.3$ & $6.2 \pm 0.3$ \\
\hline 50.0 & $52.8 \pm 1.8$ & $47.1 \pm 1.0$ & $41.4 \pm 1.1$ & $40.3 \pm 1.2$ & $30.6 \pm 0.5$ \\
\hline 125.0 & $134.1 \pm 3.2$ & $128.7 \pm 2.0$ & $90.0 \pm 1.0$ & $95.7 \pm 2.5$ & $75.5 \pm 3.0$ \\
\hline
\end{tabular}

Values are expressed as mean \pm SD.

standard solution or patients' serum was found to be excellent. Coefficient of variation for experimental samples produced using standard solutions was $4.21 \pm 3.51 \%(0 \sim 14.82)$ (intraclass correlation coefficient $=0.998)$. Coefficient of variation for experimental samples produced using serum from patients was $2.83 \pm 2.23 \%(0.87 \sim 11.21)$ (intraclass correlation coefficient $=0.999$ ).

3.2. Influence of TgAb on Measurement of Tg Using Samples Produced from Standard Solutions. Measured Tg concentration showed a proportional decline with increase of TgAb concentration in every sample produced using standard solutions. Measured Tg concentrations in samples having the lowest concentration $(10 \mathrm{U} / \mathrm{mL})$ of $\mathrm{TgAb}$ were higher than the expected Tg concentrations of the samples. However, measured $\mathrm{Tg}$ concentrations in samples having high $\mathrm{TgAb}$ were lower than expected Tg concentrations (Table 3, Figure 1).

\subsection{Influence of $\mathrm{TgAb}$ on Measurement of $\mathrm{Tg}$ Using Samples} Produced from Patients' Serum. Measured Tg concentration showed a decline with increase of $\mathrm{TgAb}$ concentration in every sample produced using patients serum. Measured Tg concentrations for all samples were found to be lower than expected Tg concentrations (Table 4, Figure 2).

\subsection{Equations for Prediction of Expected $\mathrm{Tg}$ Concentration.} Data obtained with standard solution was used in deduction of an equation for prediction of expected Tg concentrations with measured $\mathrm{Tg}$ and $\mathrm{TgAb}$ concentrations using the SAS program.

$$
\begin{aligned}
& \text { Calculated Tg }(\mathrm{ng} / \mathrm{mL}) \\
& \qquad \begin{array}{r}
=-1.553+0.592\{\text { measured Tg }(\mathrm{ng} / \mathrm{mL}) \\
\times \sqrt{\log \operatorname{TgAb}(\mathrm{U} / \mathrm{mL})}\} .
\end{array}
\end{aligned}
$$

Calculated Tg concentrations were found to be more similar to expected Tg concentrations than measured Tg concentrations, and correlation between calculated $\mathrm{Tg}$ and expected Tg concentrations was found to be excellent $\left(r^{2}=0.9869\right.$, $P<0.0001$ ) (Figures 3 and 4).

In addition, data obtained with patient serum was used in deduction of an equation for prediction of expected $\mathrm{Tg}$

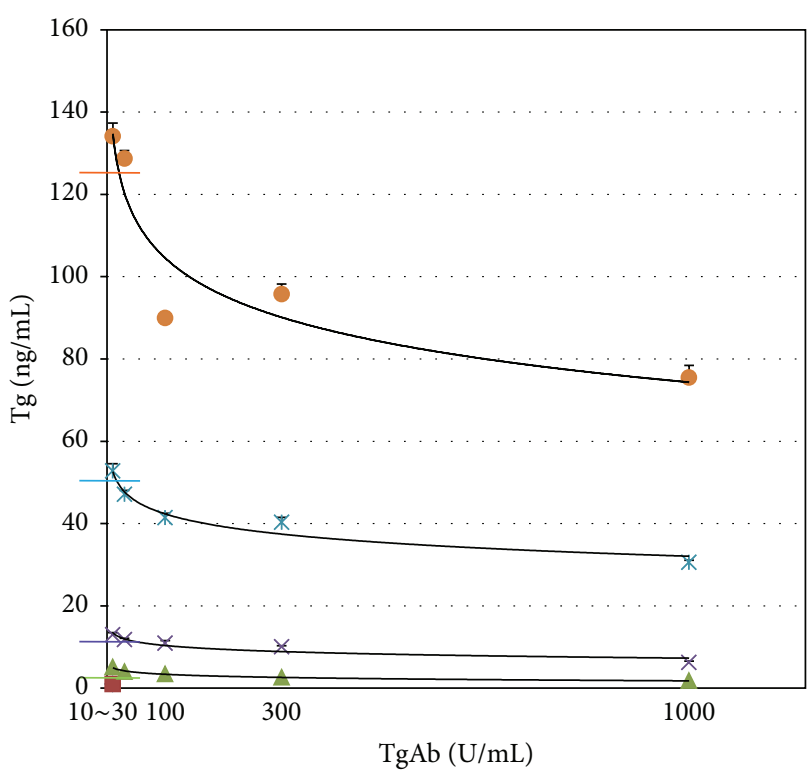

FIGURE 1: Measured Tg concentration showed a proportional decline according to increase of $\operatorname{TgAb}$ concentration in every sample produced using standard solutions. Transverse color bars represent expected Tg concentrations of each sample.

concentrations with measured $\mathrm{Tg}$ and $\mathrm{TgAb}$ concentrations using the SAS program.

$$
\begin{aligned}
& \text { Calculated } \mathrm{Tg}(\mathrm{ng} / \mathrm{mL}) \\
& =1.677+0.634 \text { measured } \mathrm{Tg}(\mathrm{ng} / \mathrm{mL}) \\
& +0.313 \text { Measured } \mathrm{Tg}(\mathrm{ng} / \mathrm{mL}) \\
& \quad \times \log \operatorname{TgAb}(\mathrm{U} / \mathrm{mL}) .
\end{aligned}
$$

Calculated Tg concentrations were found to be more similar to expected $\mathrm{Tg}$ concentrations than measured $\mathrm{Tg}$ concentrations, and correlation between calculated $\mathrm{Tg}$ and expected $\mathrm{Tg}$ concentrations was found to be excellent $\left(r^{2}=0.9727\right.$, $P<0.0001$ ) (Figures 3 and 4).

\section{Discussion}

Although the majority of patients with differentiated thyroid cancer are apparently rendered disease-free by initial treatment, approximately $15 \%$ experience persistent or 
TABLE 4: Decline of measured Tg value by mixed TgAb in samples produced using patients' serum.

\begin{tabular}{|c|c|c|c|c|c|}
\hline \multirow[t]{2}{*}{$\begin{array}{l}\text { Expected Tg concentration } \\
(\mathrm{ng} / \mathrm{mL})\end{array}$} & \multicolumn{5}{|c|}{$\begin{array}{l}\text { Measured } \mathrm{Tg} \text { concentration }(\mathrm{ng} / \mathrm{mL}) \\
\text { under various } \mathrm{TgAb} \text { concentrations }\end{array}$} \\
\hline & $3.5 \mathrm{U} / \mathrm{mL}$ & $5.2 \mathrm{U} / \mathrm{mL}$ & $18.8 \mathrm{U} / \mathrm{mL}$ & $643.0 \mathrm{U} / \mathrm{mL}$ & $930.0 \mathrm{U} / \mathrm{mL}$ \\
\hline 4.7 & $4.5 \pm 0.2$ & $4.5 \pm 0.2$ & $3.4 \pm 0.6$ & $2.1 \pm 0.1$ & $2.0 \pm 0.2$ \\
\hline 18.5 & $17.6 \pm 0.3$ & $18.7 \pm 0.4$ & $11.3 \pm 0.4$ & $9.1 \pm 0.9$ & $6.7 \pm 0.6$ \\
\hline 111.0 & $102.3 \pm 5.1$ & $100.5 \pm 5.1$ & $56.0 \pm 3.4$ & $45.3 \pm 0.4$ & $39.3 \pm 2.2$ \\
\hline 246.0 & $235.8 \pm 6.2$ & $234.8 \pm 4.2$ & $121.1 \pm 1.9$ & $99.4 \pm 12.2$ & $85.9 \pm 5.2$ \\
\hline
\end{tabular}

Values are expressed as mean \pm SD.

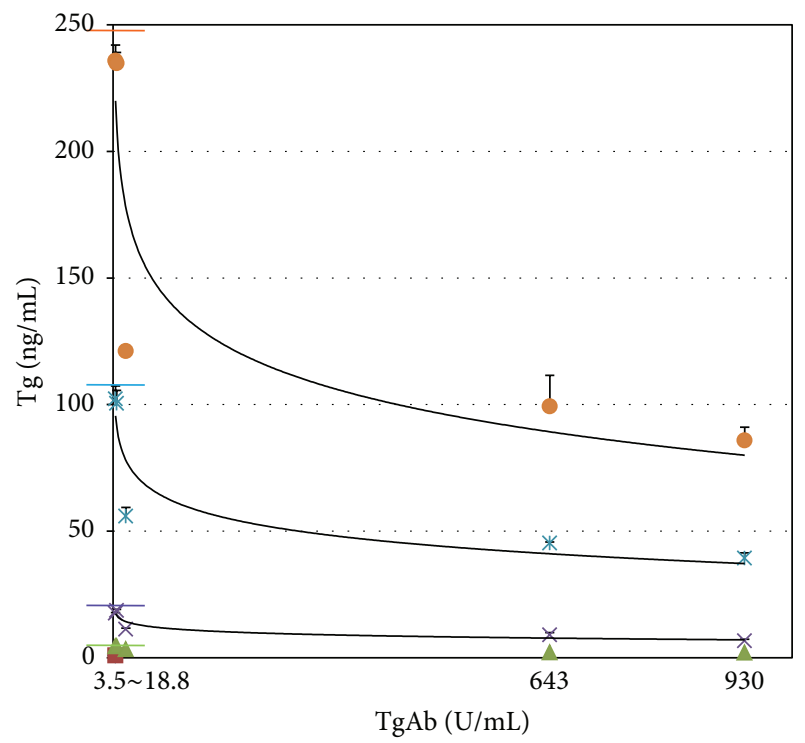

Figure 2: Measured Tg concentration in each sample produced using patients' serum showed a proportional decline according to an increase of $\mathrm{TgAb}$ concentration. Transverse color bars represent expected Tg concentrations of each sample.

recurrent cancer $[10,11]$. Persistent disease or recurrence can be predicted by measurement of serum $\mathrm{Tg}$, a sensitive and specific tumor marker for detection of differentiated thyroid cancer. Currently, the cut off value of $2 \mathrm{ng} / \mathrm{mL}$ under endogenous TSH or recombinant human TSH-stimulation is considered to represent significant risk $[1,10]$. However, cut off values from 2 to $30 \mathrm{ng} / \mathrm{mL}$, for example, $10 \mathrm{ng} / \mathrm{mL}$, have also been applied in other clinical studies $[7,12]$.

Detectable $\mathrm{TgAb}$ is reported to be associated with persistence of an antigenic stimulus, and up to $40 \%$ of patients with differentiated thyroid cancer are positive for $\mathrm{TgAb}$ [13-15]. Some reports have suggested that persistence of TgAb positivity might suggest persistent or recurrent disease in some cases of differentiated thyroid cancer; however, other studies have reported no correlation between $\mathrm{TgAb}$ level and disease persistence $[16,17]$. Therefore, the most important clinical issue with regard to high serum $\mathrm{TgAb}$ concentration is interference of the result of Tg assays with recurrence work up in patients with differentiated thyroid cancer $[8,14,17,18]$.
Endogenous $\mathrm{TgAb}$ is known to interfere with measurement of Tg in a method-dependent manner; therefore, prediction of Tg under a certain TgAb condition can be methoddependent as well [5]. Data found in the literature indicated that in the presence of $\mathrm{TgAb}$, values of $\mathrm{Tg}$ determined by immunoradiometric assay are usually lower than real values, even if the concentrations of $\mathrm{TgAb}$ are very low $[5,9,19]$. In previous reports, we observed an erroneously low measured $\mathrm{Tg}$ value according to the presence of $\mathrm{TgAb}$, and the degree showed positive correlation with concentration of $\operatorname{TgAb}[3,4]$. In the current study, influence of $\operatorname{TgAb}$ on the measurement of $\mathrm{Tg}$ was tested with experimental samples made by Tg and TgAb standard solutions or patients' serum. Two different equations which predict true Tg value were successfully deduced with the result from the tests, and the equation from the patients serum would be more appropriate for clinical application. According to findings from the current study, true Tg values in high concentrations of $\mathrm{TgAb}$ are more than twice the measured values. Serum with a true $\mathrm{Tg}$ value of $4.7 \mathrm{ng} / \mathrm{mL}$ can be measured as $2 \mathrm{ng} / \mathrm{mL}$ in samples containing a TgAb concentration of $1860 \mathrm{U} / \mathrm{mL}$. It can be assumed that measured Tg value for a patient with a $\mathrm{Tg}$ of $4.7 \mathrm{ng} / \mathrm{mL}$ and a TgAb greater than $1860 \mathrm{U} / \mathrm{mL}$ might be a Tg of less than $2.0 \mathrm{ng} / \mathrm{mL}$ using the Tg assay. As a result, when applying a Tg cut off value of $2.0 \mathrm{ng} / \mathrm{mL}$, the patient can be misclassified as low risk for recurrent or persistent disease. Serum with a true $\mathrm{Tg}$ value of $18.5 \mathrm{ng} / \mathrm{mL}$ can be measured as $9.1 \mathrm{ng} / \mathrm{mL}$ in samples containing a $\mathrm{TgAb}$ concentration of $1286 \mathrm{U} / \mathrm{mL}$. It can also be assumed that measured $\mathrm{Tg}$ value for a patient with a $\mathrm{Tg}$ of $18.5 \mathrm{ng} / \mathrm{mL}$ and $\mathrm{TgAb}$ greater than $1286 \mathrm{U} / \mathrm{mL}$ might be a Tg of less than $10 \mathrm{ng} / \mathrm{mL}$ using the $\mathrm{Tg}$ assay. As a result, when applying a $\mathrm{Tg}$ cut off value of $10 \mathrm{ng} / \mathrm{mL}$, the patient can be misclassified as low risk for recurrent or persistent disease.

Higher incidence of positive $\mathrm{TgAb}$ in patients with differentiated thyroid cancer, compared with the general population, has been reported. In addition, some patients have a high concentration of $\operatorname{TgAb}[14,18]$. Considering the results of the current study, some patients with a borderline $\mathrm{Tg}$ value can be misclassified into a low risk group and therefore would not undergo further diagnostic evaluation to detect recurrence or persistent disease. Management of disease can be delayed and prognosis of patients might be worse than that for patients diagnosed earlier with recurrence or persistent disease. 


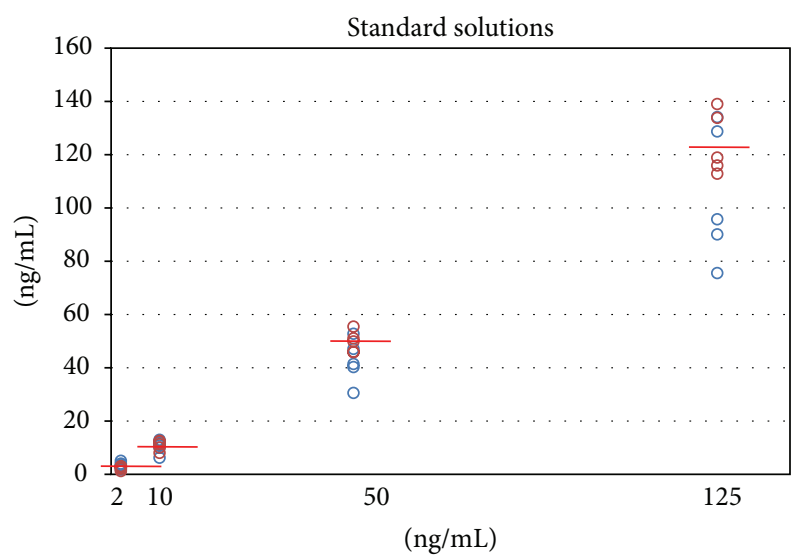

$\bigcirc$ Measured

C Calculated

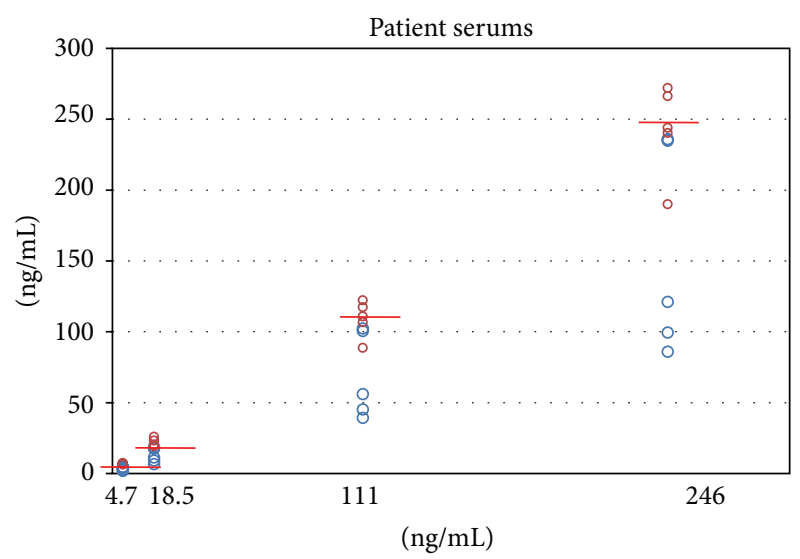

$\bigcirc$ Measured

$\bigcirc$ Calculated

(a)

FIgURE 3: For each concentration of TgAb, the calculated Tg concentrations were more similar to expected Tg concentrations than measured Tg concentrations in samples from both standard solution and patients' serum.

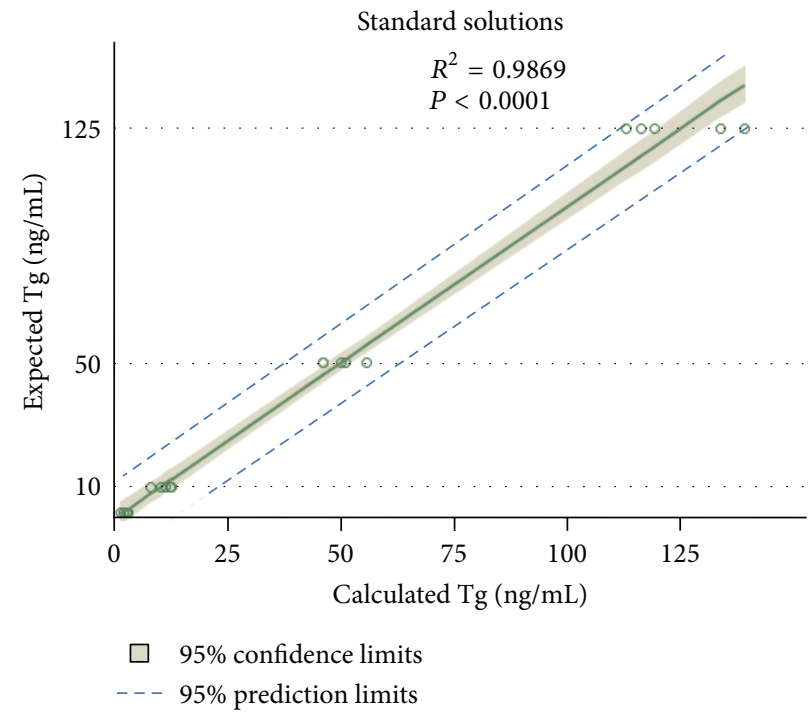

(a)

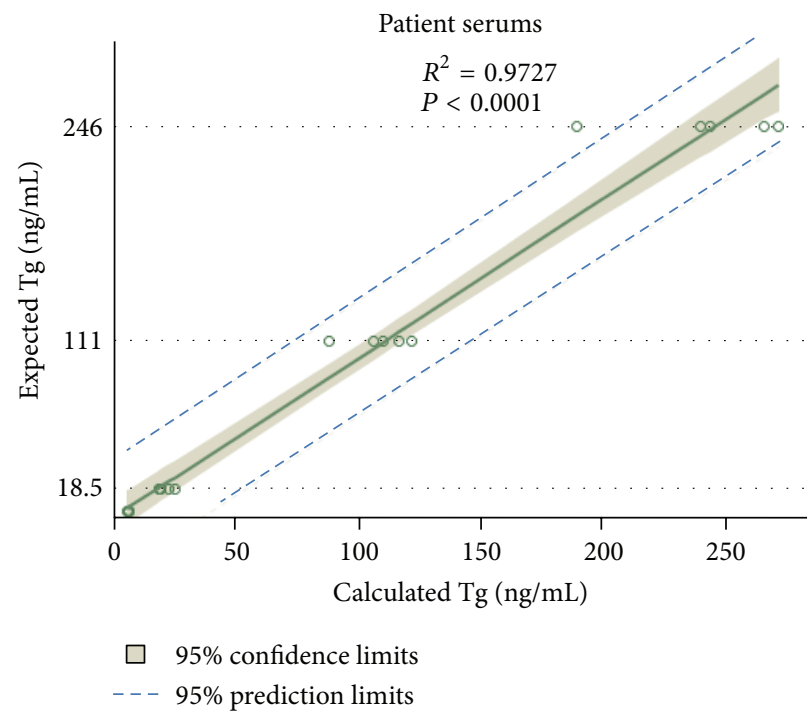

(b)

FIGURE 4: Correlations between the calculated Tg and expected Tg concentrations were found to be excellent in samples produced from both standard solution and patients' serum.

Consideration of $\operatorname{TgAb}$ when deciding on the clinical significance of $\mathrm{Tg}$ value has been basically by the presence or absence of $\mathrm{TgAb}$ only $[1,20]$. It had been generally regarded that $\operatorname{TgAb}$ titer measured is below a clinical threshold will not be a significant influence on the Tg outcome; however, recent studies demonstrated that $\mathrm{TgAb}$ below the cut off can interfere the Tg outcome $[19,21]$. Recently, Locsei et al. also reported that the measured $\mathrm{Tg}$ value of patients serum can be influenced by mixing sheep $\operatorname{TgAb}$ in the reference range of $\operatorname{TgAb}$ concentration and deduced an equation estimating true $\mathrm{Tg}$ concentration using $\mathrm{TgAb}$ concentration in the same sample [9]. They proved the general concept of $\operatorname{TgAb}$ influence on the Tg measurement; however, their equation cannot be generally applied to clinical practice due to difference between sheep $\operatorname{TgAb}$ and human $\operatorname{TgAb}$. Verification of the $\operatorname{TgAb}$ influence using human $\operatorname{TgAb}$, not sheep $\operatorname{TgAb}$, is needed for that purpose.

In the current study, we used human $\mathrm{TgAb}$ from patients' serum for assessment of the influence of Tg to the Tg assay, and verified the same significant influence of human $\mathrm{TgAb}$ in reference range to the $\mathrm{Tg}$ assay. Results of this study demonstrated that concentration of human $\mathrm{TgAb}$ in the reference range also can result in a significantly lower measured $\mathrm{Tg}$ value, and a high concentration of $\mathrm{TgAb}$ can result in 
the measured $\mathrm{Tg}$ value even lower; therefore, development of methods for use by clinicians in consideration of concomitant low or high concentration of $\mathrm{TgAb}$ for determination of the clinical significance of measured $\mathrm{Tg}$ values is a pressing issue. In contrary to experiment employing patients' serums, low concentration of $\mathrm{TgAb}$ incurred an overestimation of $\mathrm{Tg}$ in the experiment employing the standard solutions and elucidation of the cause was not performed in the current study.

Magnitude of the influence is known to not only depend on the class of assay methods, but also the type of $\mathrm{Tg}$ epitope recognized by patient's $\operatorname{TgAb}[16,18,22]$. Therefore, development of an equation that can be applied to all assay methods and all patients might not be possible. In this study, there was a large deviation of many of the actual points from the curve fits on Figures 1 and 2, suggesting that the back calculation of the true $\mathrm{Tg}$ value according to the equation might give quite erroneous results in some patients. The deviation probably originates from the interpatient variability of influence magnitude related to heterogeneity of patients' $\mathrm{TgAb}$. However, results of the current study demonstrated that the Tg value calculated by the equation is generally close to the true $\mathrm{Tg}$ value than the measured $\mathrm{Tg}$ value. Based on the results, the corrected $\mathrm{Tg}$ value by the equation might be more valuable than measured $\mathrm{Tg}$ value for predicting the presence or recurrence of a cancerous lesion in patients with differentiated thyroid cancer. However, in fact, clinical validation studies are needed for allowing physician to implement the approach in clinical laboratory practice.

This study has limitations. First, despite efforts to standardize thyroglobulin analytes across assay platforms, differences between platforms persist and can be related to genetic polymorphisms that introduce changes in protein primary structure, glycosylation pathways which could lead to variable protein processing, modification, or cross-linking $[6,8]$. Result of TgAb assays was also known to be discordant by their epitope pattern, especially in patients without thyroiditis [23]. The equation would differ according to the assay platforms used for measurement of $\mathrm{Tg}$ and $\mathrm{TgAb}$ and it cannot be generalized. Therefore, institution's own equation has to be developed by the specific combination of Tg and $\mathrm{TgAb}$ assays used. Second, we did not evaluate the influence of $\mathrm{Tg}$ on measurement of $\mathrm{TgAb}$. For estimation of true $\mathrm{Tg}$ value using measured $\mathrm{Tg}$ and $\operatorname{TgAb}$ values, the true $\mathrm{TgAb}$ value should be plugged into the equation. The influence of $\mathrm{Tg}$ on $\mathrm{TgAb}$ assay must also be considered [18]. Third, expected $\mathrm{Tg}$ and $\mathrm{TgAb}$ values might be inaccurate in samples produced using patients serum owing to presence of $\mathrm{Tg}$ in serum for $\mathrm{TgAb}$ and presence of $\mathrm{TgAb}$ in sera for $\mathrm{Tg}$, albeit they are very low in titer. Fourth, in this study, we used only four concentrations of $\mathrm{Tg}$ and five concentrations of $\mathrm{TgAb}$. Therefore, the equation formula for estimating true $\mathrm{Tg}$ concentration is not the most accurate one, and further studies are needed in order to develop the most accurate equation for estimation of true $\mathrm{Tg}$ concentration using measured $\mathrm{Tg}$ and $\mathrm{TgAb}$ concentrations.

In conclusion, findings from this study demonstrate a mathematic equation for prediction of true Tg concentration using measured $\mathrm{Tg}$ and $\mathrm{TgAb}$ concentrations. The true $\mathrm{Tg}$ concentration calculated by the equation might be more valuable than measured $\mathrm{Tg}$ value for predicting the presence of residual or recurrent cancerous lesions in patients with differentiated thyroid cancer.

\section{Conflict of Interests}

The authors have no conflict of interests.

\section{Acknowledgments}

This work was supported by Grants (A102132, A111345) from the Korea Health Technology R\&D Project, Ministry of Health \& Welfare, Republic of KOREA, a grant from the National Nuclear R\&D Program through the National Research Foundation of Korea (NRF) funded by the Ministry of Education, Science and Technology (no. 2012M2A2A7014020), and a grant from the National Research Foundation of Korea (NRF) grant funded by the Korea government (MEST) (no. 2012-0004878, 2012-0004879).

\section{References}

[1] D. S. Cooper, G. M. Doherty, B. R. Haugen et al., "Revised American thyroid association management guidelines for patients with thyroid nodules and differentiated thyroid cancer," Thyroid, vol. 19, no. 11, pp. 1167-1214, 2009.

[2] C. Reiners, M. Dietlein, and M. Luster, "Radio-iodine therapy in differentiated thyroid cancer: indications and procedures," Best Practice and Research: Clinical Endocrinology and Metabolism, vol. 22, no. 6, pp. 989-1007, 2008.

[3] B. Ahn, J. Seo, J. Bae et al., "Effects of anti-thyroglobulin antibody on the measurement of thyroglobulin: differences between immunoradiometric assay kits available," Korean Journal of Nuclear Medicine, vol. 39, no. 4, pp. 252-256, 2005.

[4] B. Ahn, J. Bae, S. Jeong et al., "Influence of anti-thyroglobulin antibody on the measurement of thyroglobulin using the immunoradiometric assay," Journal of Korean Society of Endocrinology, vol. 19, no. 1, pp. 42-47, 2004.

[5] M. Stanojević, S. Savin, D. Cvejić, A. Dukić, and S. Z. Simonović, "Correlation of thyroglobulin concentrations measured by radioimmunoassay and immunoradiometric assay and the influence of thyroglobulin antibody," Journal of Immunoassay and Immunochemistry, vol. 30, no. 2, pp. 197-207, 2009.

[6] C. A. Spencer and J. S. LoPresti, “Technology Insight: measuring thyroglobulin and thyroglobulin autoantibody in patients with differentiated thyroid cancer," Nature Clinical Practice Endocrinology and Metabolism, vol. 4, no. 4, pp. 223-233, 2008.

[7] G. Aras, S. S. Gültekin, N. Ö. Küçük, and Y. Genç, "Is thyroglobulin the stronger indicator for progressive disease than the other conventional factors in same age patient groups with differentiated thyroid cancer?" Nuclear Medicine Communications, vol. 28, no. 12, pp. 907-913, 2007.

[8] A. N. Hoofnagle and M. H. Wener, "The fundamental flaws of immunoassays and potential solutions using tandem mass spectrometry," Journal of Immunological Methods, vol. 347, no. 1-2, pp. 3-11, 2009.

[9] Z. Locsei, I. Szabolcs, K. Rácz, G. L. Kovács, D. Horváth, and E. Toldy, "Serum thyroglobulin antibody levels within or near to the reference range may interfere with thyroglobulin 
measurement," Biochemical Medicine, vol. 22, no. 3, pp. 365-370, 2012.

[10] C. Spencer, S. Fatemi, P. Singer, J. Nicoloff, and J. Lopresti, "Serum basal thyroglobulin measured by a second-generation assay correlates with the recombinant human thyrotropinstimulated thyroglobulin response in patients treated for differentiated thyroid cancer," Thyroid, vol. 20, no. 6, pp. 587-595, 2010.

[11] E. L. Mazzaferri and R. T. Kloos, "Current approaches to primary therapy for papillary and follicular thyroid cancer," The Journal of Clinical Endocrinology \& Metabolism, vol. 86, no. 4, pp. 1447-1463, 2001.

[12] S. Leboulleux, P. R. Schroeder, N. L. Busaidy et al., "Assessment of the incremental value of recombinant thyrotropin stimulation before 2-[18F]-fluoro-2-deoxy-D-glucose positron emission tomography/computed tomography imaging to localize residual differentiated thyroid cancer," The Journal of Clinical Endocrinology \& Metabolism, vol. 94, no. 4, pp. 1310-1316, 2009.

[13] C. A. Spencer, M. Takeuchi, M. Kazarosyan et al., "Serum thyroglobulin autoantibodies: prevalence, influence on serum thyroglobulin measurement, and prognostic significance in patients with differentiated thyroid carcinoma," The Journal of Clinical Endocrinology \& Metabolism, vol. 83, no. 4, pp. 11211127, 1998.

[14] D. Madureira, S. Prazeres, M. S. Pedro, T. Pereira, A. P. Font, and M. J. Bugalho, "In vitro assays to test the interference of anti-thyroglobulin antibodies on thyroglobulin measurement," Endocrine, vol. 33, no. 1, pp. 40-44, 2008.

[15] L. Chiovato, F. Latrofa, L. E. Braverman et al., "Disappearance of humoral thyroid autoimmunity after complete removal of thyroid antigens," Annals of Internal Medicine, vol. 139, no. 5, pp. 346-351, 2003.

[16] C. A. Spencer, "Clinical review: clinical utility of thyroglobulin antibody (TgAb) measurements for patients with differentiated thyroid cancers (DTC)," The Journal of Clinical Endocrinology \& Metabolism, vol. 96, pp. 3615-3627, 2011.

[17] J. H. Seo, S. W. Lee, B. C. Ahn, and J. Lee, "Recurrence detection in differentiated thyroid cancer patients with elevated serum level of antithyroglobulin antibody: special emphasis on using 18F-FDG PET/CT,' Clinical Endocrinology, vol. 72, no. 4, pp. 558-563, 2010.

[18] Y. Gao, Z. Yuan, Y. Yu, and H. Lu, "Mutual interference between serum thyroglobulin and antithyroglobulin antibody in an automated chemiluminescent immunoassay," Clinical Biochemistry, vol. 40, no. 9-10, pp. 735-738, 2007.

[19] C. Spencer, I. Petrovic, and S. Fatemi, "Current thyroglobulin autoantibody (TgAb) assays often fail to detect interfering $\mathrm{TgAb}$ that can result in the reporting of falsely low/undetectable serum Tg IMA values for patients with differentiated thyroid cancer," The Journal of Clinical Endocrinology \& Metabolism, vol. 96, no. 5, pp. 1283-1291, 2011.

[20] F. Berger, U. Friedrich, P. Knesewitsch, and K. Hahn, "Diagnostic 131I whole-body scintigraphy 1 year after thyroablative therapy in patients with differentiated thyroid cancer: correlation of results to the individual risk profile and long-term follow-up," European Journal of Nuclear Medicine and Molecular Imaging, vol. 38, no. 3, pp. 451-458, 2011.

[21] F. Latrofa, D. Ricci, L. Montanelli et al., "Lymphocytic thyroiditis on histology correlates with serum thyroglobulin autoantibodies in patients with papillary thyroid carcinoma: impact on detection of serum thyroglobulin," The Journal of Clinical Endocrinology \& Metabolism, vol. 97, no. 7, pp. 2380-2387, 2012.
[22] F. Latrofa, D. Ricci, L. Grasso et al., "Characterization of thyroglobulin epitopes in patients with autoimmune and nonautoimmune thyroid diseases using recombinant human monoclonal thyroglobulin autoantibodies," The Journal of Clinical Endocrinology \& Metabolism, vol. 93, no. 2, pp. 591-596, 2008.

[23] F. Latrofa, D. Ricci, L. Montanelli et al., “Thyroglobulin autoantibodies in patients with papillary thyroid carcinoma: comparison of different assays and evaluation of causes of discrepancies," The Journal of Clinical Endocrinology \& Metabolism, vol. 97, no. 11, pp. 3974-3982, 2012. 


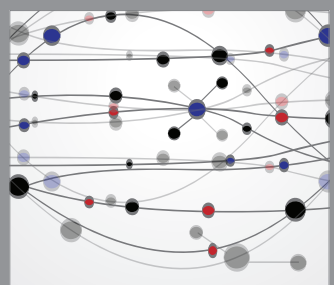

The Scientific World Journal
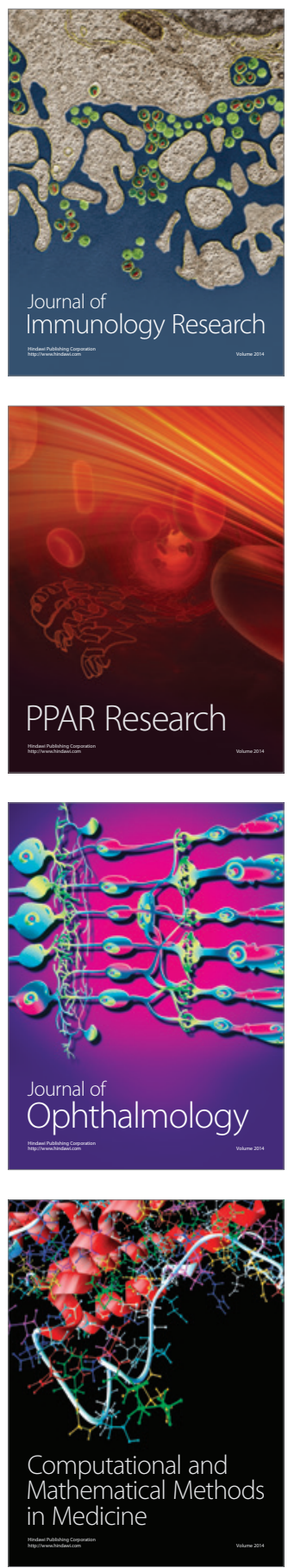

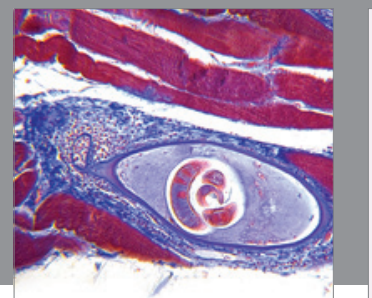

Gastroenterology

Research and Practice
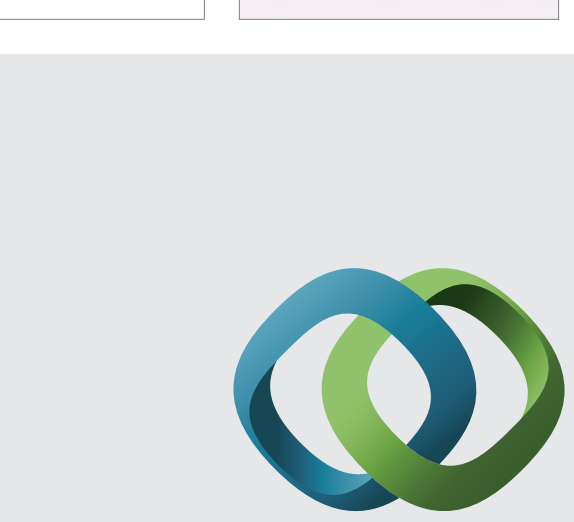

\section{Hindawi}

Submit your manuscripts at

http://www.hindawi.com
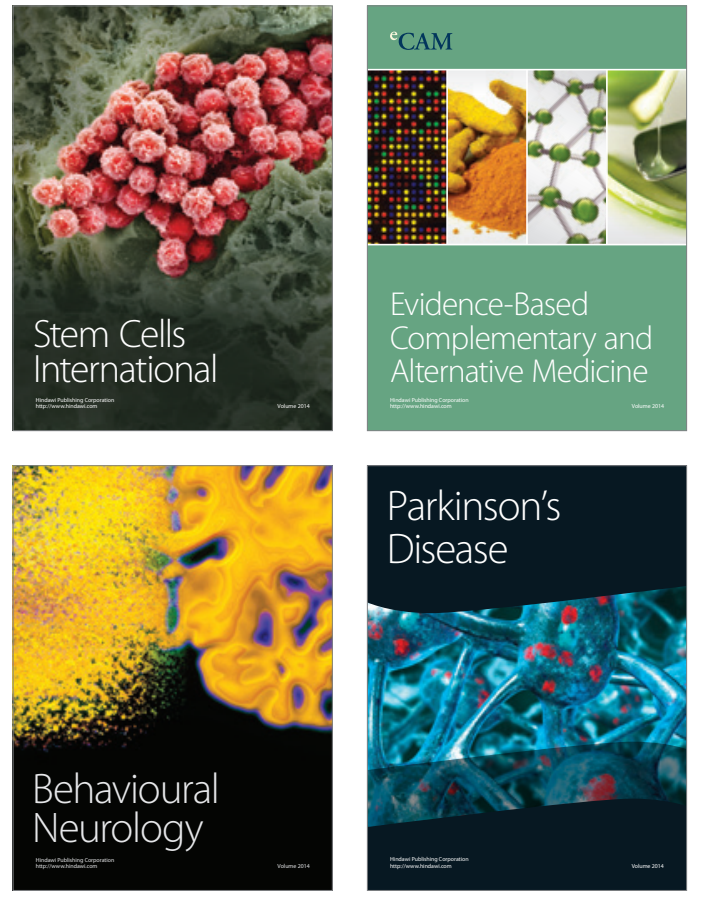
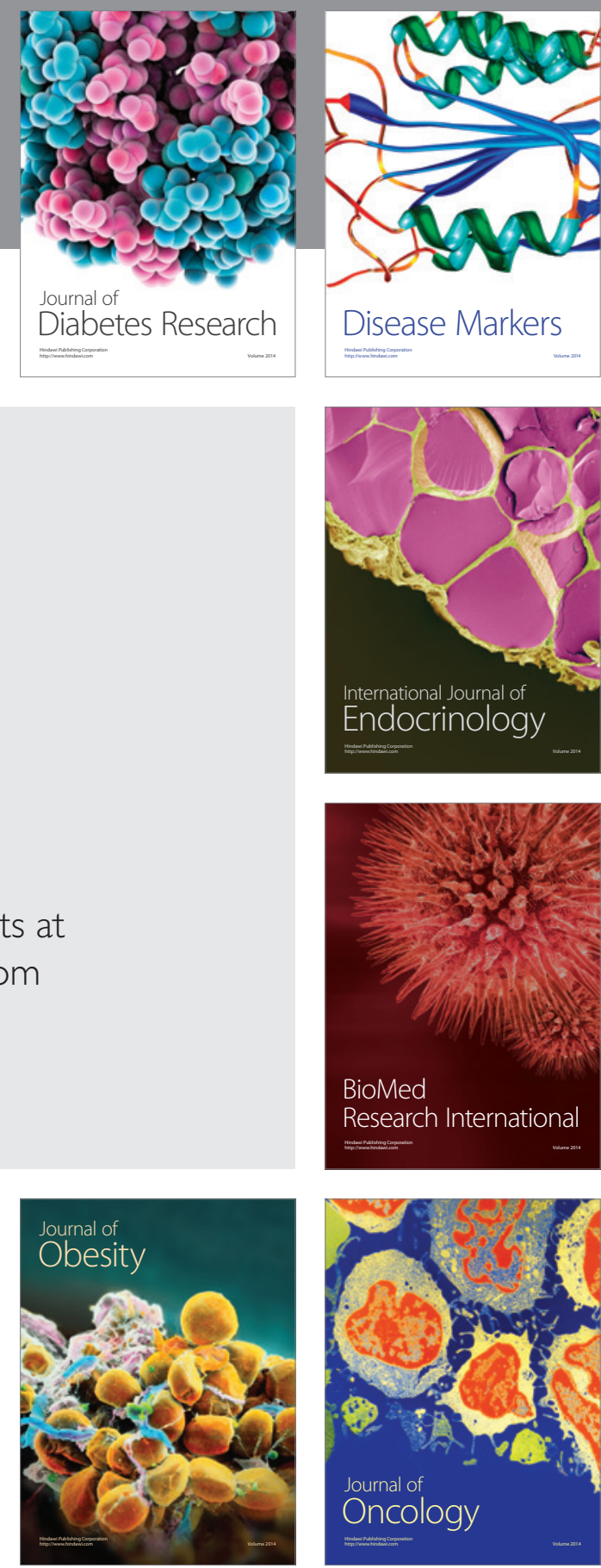

Disease Markers
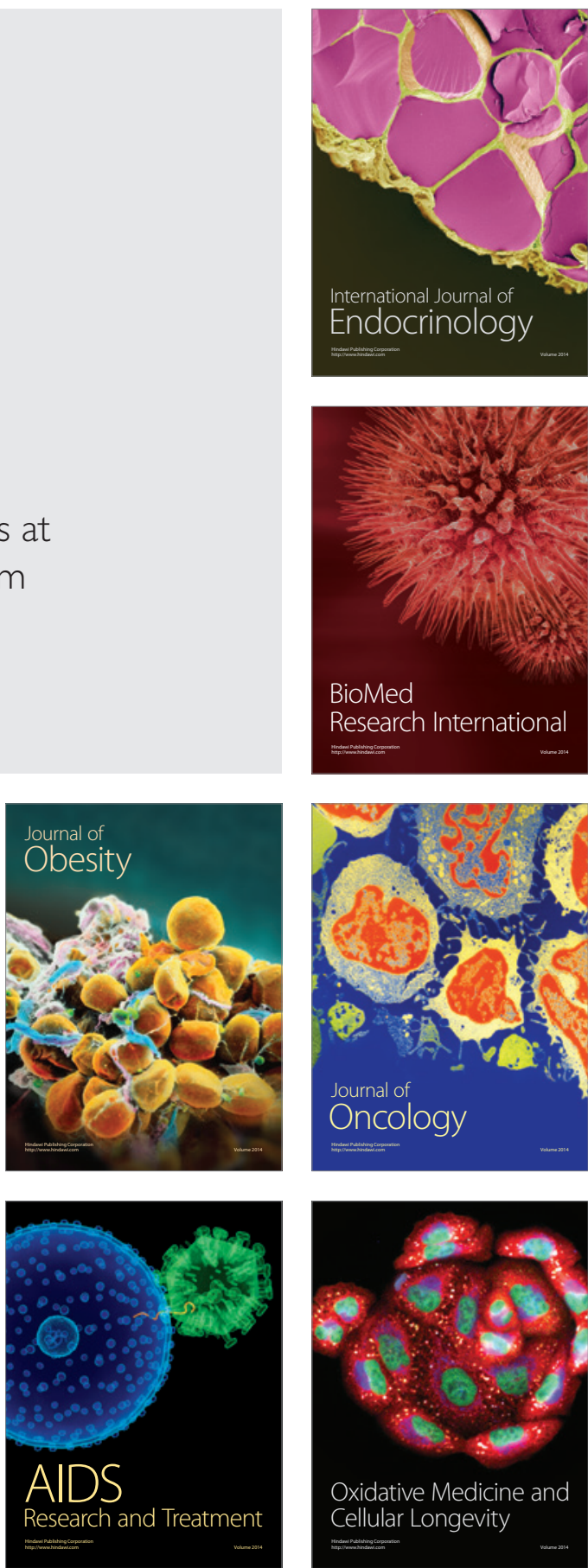